\title{
Differentiating the Curriculum to Achieve "Learner Growth" when using 1:1 Mobile Devices for Learning
}

\author{
By Arthur Firipis", Siva Chandrasekaran ${ }^{\dagger} \&$ \\ Matthew Joordens
}

\begin{abstract}
With the increasing use of 1:1 mobile devices within the curriculum space, differentiating its use to support "learner growth" has become an important discussion amongst policy makers, researchers, educators and learners. This research study provides an insight into how learners are using their 1:1 mobile device to support their learning process. The premise of the discussion begins with the notion that a learner's success is dependent on the curriculum design been sufficiently differentiated using resources and scaffolding. Differentiating to develop technical skills that will lead to the production of artefacts as evidence of learning and creativity. This research study highlights the role of the digitally literate educational leader who can apply self-directed differentiation learning theory to model the use of 1:1 mobile devices to support "learner growth". The research study reveals learners come with pre, during and post learning perceptions, and understandings about how 1:1 mobile devices can be used to support their "learning growth". These perceptions and motivations for learning will need to be considered along with self-directed learning theory and applied to the delivery of linear and non-linear curriculum design.
\end{abstract}

Keywords: 1:1 mobile device technology, educational psychology, learning, critical thinking, differentiation and curriculum design.

\section{Introduction}

With the increasing use of 1:1 mobile devices within the curriculum space, differentiating its use to support "learner growth" has become an important discussion amongst policy makers, researchers, educators and learners. This research study provides an insight into how learners are using their 1:1 mobile device to support their learning process. The premise of the discussion begins with the notion that a learner's success is dependent on the curriculum design been sufficiently differentiated using resources and scaffolding. Differentiating to develop technical skills that will lead to the production of artefacts as evidence of learning and creativity. This research study highlights the role of the digitally literate educational leader who can apply self-directed differentiation learning theory to model the use of 1:1 mobile devices to support "learner growth". The research study reveals learners come with pre, during and post learning

${ }^{*}$ PhD Student Researcher, Deakin University, Australia.

${ }^{\dagger}$ Lecturer, Swinburne University of Technology, Melbourne, Australia.

${ }^{\ddagger}$ Associate Professor, Deakin University, Australia. 
perceptions, and understandings about how 1:1 mobile devices can be used to support their "learning growth". These perceptions and motivations for learning will need to be considered along with self-directed learning theory and applied to the delivery of linear and non-linear curriculum design.

Tomlinson (2017) states, "The presumptive 'ability' we assign to a student too often becomes a sort of pedagogical predestination." Boser et al. (2014) reflects on a learning experience stating, "... the device erases disabilities that might otherwise be visible and humiliating. When all the answers are typed or spoken into the computer, every student's paper or audio response is as readable and understandable as any other." Grigorenko \& Sternberg (1997) state, "... the way an individual interacts with and processes experiences will vary and will have a tremendous influence on the way they learn." Fischer and Bidell (2006) conducted research using digital technologies such as fMRI (Functional Magnetic Resonance Imaging) and PET (Position Emission Tomography) brain activity scans, monitoring the human brain while active learning and completing tasks concluded, "... learners are highly variable and learning is highly dependent on the context." ${ }^{1,2}$ Fischer and Bidell, (2009), Siegler (1994), Van Geert \& Fischer (2009) provide supporting conclusions that every person is unique based on their natural genetic diversity (nature) and influenced by experiences over time (nurture). These experienced observers echo the complexity and humanity behind every decision an educator must make on behalf of their learners. Even within the broader context of emerging virtual learning spaces, differentiation becomes the "driving force" that positions the quality of the educational experience for all learners.

This research study provides an insight into how learner perceptions and motivations are influenced by the use of 1:1 mobile devices for learning within the context of a higher education engineering course. The research study results and discussion are presented as follows;

- Part A - Q.1 to 8 - Perceptions of Readiness to Learn;

- Part B - Q.9 to 14 - Learner Perceptions of Learning;

- Part C - Q.15 to 20 - Learner Perceptions when using 1:1 Mobile Devices

- Part D-Q. 21 to 25 - Bonus Materials Perceptions;

- Part E - Learning Growth Measurement (Effect Size).

The significance of this research study provides a discussion about the relevance of self-directed learning theory within the context of learners using 1:1 mobile devices. It raises further questions about how self-directed learning might affect academic success, how can curriculum differentiation theory be used to support educational leaders, to what extent will digital literacy influence future occupational choices, how does digital literacy improve learning, and what

\footnotetext{
${ }^{1}$ fMRI stands for functional Magnetic Resonance Imaging. The term "functional" indicates that this type of MRI is concerned with brain function during a specific experimental time period, as opposed to the static MRI most often used to diagnose brain (and other tissue) pathology.

${ }^{2}$ PET stands for "positron emission tomography". It is a nuclear medicine imaging test in which a small amount of liquid radioactive material is injected into the body and is used to diagnose a variety of diseases, including many types of cancers, and brain and heart disease.
} 
learning interventions will help learners to understand and adjust to self-directed learning when using 1:1 mobile devices. The survey instrument developed during this research study will be useful for educational leaders attempting to differentiate the learning classroom during formative assessment processes and will help learners articulate their learning perceptions and motivations for wanting to use 1:1 mobile devices to achieve learning outcomes.

\section{Definition}

1:1 mobile devices are defined as a portable handheld 1:1 device include iPad, mobile phone, Tablet or similar handheld Wi-Fi or Internet accessible device.

\section{Research Methodology}

In consultation with the research authors, a library search protocol was developed before the literature search commencing. A mixed search strategy via accessing electronic databases and drawing on library held hard copy resources was undertaken during 2017-18. The following electronic resources were accessed during the search:

- EBSCO (Elton B. Stephens Company) digital library service ${ }^{3}$

- IEEE (Institute of Electrical and Electronics Engineers) digital library service; and

- Google Scholar ${ }^{4}$

Keywords were used to facilitate searches: critical thinking, higher-order thinking, differentiated learning, active learning, self-regulated learning, differentiation, learning motivation, learning theory, mobile technology, mlearning, mobile learning, digital learning, tablet, iPad; 1:1 mobile device, instruction, instructional, learning, and Engineering learning. These search terms were chosen as they are the terms frequently used when describing mobile learning. Studies were included in the literature review if they were prepared by recognised peer-reviewed academics and research published by recognized academic publishers, and contributed to explaining the application of differentiation learning theories. Excluded from the literature search were studies not contextualised within a higher education setting and did not include a discussion involving differentiated learning. The guiding question for the literature review is: "How can learning growth be developed in the curriculum using differentiation when using 1:1 Mobile Devices for learning?"

The literature review includes the differentiation theories that contextualise and attempt to understand the links between educational leadership, differentiation occurring during the summative assessment and "learner growth" when using 1:1 mobile devices. Comparative study results from Vermunt (1998) is included to

\footnotetext{
${ }^{3}$ http://search.ebscohost.com/

${ }^{4}$ http://scholar.google.co.uk/
} 
contextualise this study. This literature review is limited to acknowledging that early differentiating learning theory did not include a discussion about mobile technologies as a learning tool.

\section{Learning Growth Measurement}

An online pre-test of eight (8) questions was given to the students to determine KWL (What you KNOW, WHAT you want to LEARN, WHAT have you LEARNT) to determine misunderstandings and current knowledge before commencing the course of study. The pre-test results were collected and used as a measured benchmark of "learning growth". This was compared with final course results using Hattie's effect size methodology.

Hattie Effect Size. Effect size is measured by the number of standard $d=g \sqrt{\frac{N}{N-2}}$ deviations the means differ by. Cohen's deviation calculation which divides by $\mathrm{N}$. The formula used is shown. Effect size = Average - Average Spread (standard deviation, or SD).

\section{Online Survey}

The survey instrument aimed to identify learner perceptions of readiness to learn, perceptions of learning in progress, and perceptions of learning when using 1:1 mobile devices for learning. The survey instrument was modelled on research undertaken by Guglielmino (1977) Self Directed Learning Readiness (SDLR) and Vermunt (1998) Individual Learning Process (ILP). Firipis et al. (2016) tested an experimental survey instrument before the final online version of twenty-five questions were agreed upon for use in this research study. Responses were received from first to third year Engineering students enrolled between 2016 and 2017. Participants were aged between 18 to 35 years old (10\% females and $90 \%$ males). The sample comprised of 180 volunteers recruited using approved research ethics guidelines for human research studies. Data returned 68 valid responses which were de-identified, compiled and analysed using small sample methodology using an Excel spreadsheet (see Table 1). Whisker graphs were also used to represent the results for comparisons.

Table 1. Small Sample

\begin{tabular}{|l|l|}
\hline Number of Responses & 37 \\
\hline Mean & 4.27027027 \\
\hline SD & 0.651862658 \\
\hline Spec & 4 \\
\hline Z & 0.414612291 \\
\hline$\%$ & $66.1 \%$ \\
\hline CV & $15 \%$ \\
\hline & Number \\
\hline Top Box & $14(37.8 \%)$ \\
\hline Top 2 Box & $33(89.2 \%)$ \\
\hline Agree & $33(89.2 \%)$ \\
\hline Net Top Box & $14(37.8 \%)$ \\
\hline
\end{tabular}




\section{Hypothesis}

If, 1:1 mobile devices are being used for learning, then there will be an improved perception of student engagement in the engineering unit of study. If, a measured perception of student engagement does exist, then, this will lead to measured learning growth.

\section{Literature Review}

\section{Defining Differentiation}

Tomlinson (2017) defines differentiating instruction as a means of redefining the learning in the classroom, providing learners with multiple entry points for taking in information, analysing and to discover existing and new ideas; and to produce products as an expression of creativity. Tomlinson (2017) explains that in a differentiated classroom, educational leaders aim to demonstrate three curricular elements:

1. content input; what students learn;

2. process; how students go about making sense of ideas and information; and

3. product; output, or how students demonstrate what they have learnt.

Rose, Meyer, \& Hitchcock, (2005) defined differentiation within a framework, "Universal Design for Learning", standardizing principles of learning using multiple representations to cater for learners regardless of ability (disability). For example, differentiating individual students learning with Autism Spectrum Disorder (ASD) using interactive technologies, for example, digital whiteboards blending video and interactive games fostering tactile and kinaesthetic delivery and adapting different learning strategies to foster student learning growth.

\section{What Differentiation is Not}

Tomlinson (2017) argues differentiation is not "individualised learning' where individual lesson plans are prepared for each of the thirty students in every subject or unit, delivered sequentially every hour of the academic day. The assumption that meaningful learning would result from the teacher's leading of whole class, small group and individualised learning activities is unsupported despite its popularity. Differentiation is linked to the teacher's ability to lead rather than the necessity to rely on classroom management using rules to motivate students to learn. An experienced teacher can motivate students by building on individual learner's interests, creating a culture of inquiry-based learning using self-directed learning principals. Tomlinson (2017) argues effective educational leadership is a measure of collaborative learning where individual and whole group activities result in a "mind-set" leading to a measured "learning growth". 
The concept of student "learning growth" is relatively new in the literature and is defined as agreed understandings between the teacher and the student. Tomlinson (2017) argues, "learning growth" is achieved when students can work collaboratively and independently within a framework of self-determined understanding of classroom rules and learning expectations. The subtle re-focus on the teacher's ability to lead and shape the student's "mindset" has a profound effect on how students develop their own "learning growth".

\section{Differentiation through Educational Leadership}

The educator's leadership role is to teach students how to differentiate their own learning through modelling and developing life-long learning skills. The implications of this "mind-set" of differentiation reset the way curriculum design, and delivery is viewed. Tomlinson (2017) explains, "Fluidity" in the way a teacher identifies student strengths, allowing for movement within a collaborative learning environment to allow freedom for students to share their skills and knowledge; and also, to acknowledge their weaknesses and build capacity to achieve "learning growth".

Table 2. Hattie (2009) Visible Learning - Domain Effect Size

\begin{tabular}{|l|c|c|c|c|}
\hline Dimension & Studies & Meta-Analysis & No. of Effects & Effect Size \\
\hline Student & 11,909 & 152 & 40,197 & 0.39 \\
\hline Home & 2,347 & 40 & 6,031 & 0.31 \\
\hline School & 4,688 & 115 & 15,536 & 0.23 \\
\hline Teacher & $\mathbf{2 , 4 5 2}$ & $\mathbf{4 1}$ & $\mathbf{6 , 0 1 4}$ & $\mathbf{0 . 4 7}$ \\
\hline Curricula & 10,129 & 153 & 32,367 & 0.45 \\
\hline Teaching & 28,642 & 412 & 59,909 & 0.43 \\
\hline Average & $\mathbf{6 0 , 1 6 7}$ & $\mathbf{9 1 3}$ & $\mathbf{1 6 0 , 0 5 4}$ & $\mathbf{0 . 4 0}$ \\
\hline
\end{tabular}

Effect size $=$ Average - Average Spread (standard deviation, or SD)

Source: Hattie (2009). Visible learning: A synthesis of $800+$ meta-analyses on achievement. London: Routledge.

Hattie (2018) researched effect size, and supports this view that "... an important influence on student achievement is how the teacher thinks about learning and their role as a professional educator." In Table 2 - Hattie (2009) Visible Learning Domain Effect Size, showing the role of the teacher as a significant influencer.

\section{Diagnostic Assessment for Differentiation}

Vermunt (1998), Volet, McGill, and Pears (1995), Duffy and Jonassen (1992), and Pask (1976) research suggests the ongoing improvement of the quality of learning is reliant on cognitive self-directed learning approaches to support "deep learning" when differentiating the curriculum to achieve a "learning growth" outcome. 
Table 3. Vermunt (1998) Individual Learning Process (ILP) - Regulation Strategies, Mental Learning Models and Learning Orientations

\begin{tabular}{|l|c|c|c|c|c|c|c|c|c|c|}
\hline $\begin{array}{l}\text { Processing } \\
\text { strategies }\end{array}$ & \multicolumn{2}{|c|}{$\begin{array}{c}\text { Relating \& } \\
\text { structuring }\end{array}$} & \multicolumn{2}{c|}{$\begin{array}{c}\text { Critical } \\
\text { processing }\end{array}$} & \multicolumn{2}{c|}{$\begin{array}{c}\text { Memorising \& } \\
\text { rehearsing }\end{array}$} & \multicolumn{2}{|c|}{ Analysing } & \multicolumn{2}{c|}{$\begin{array}{c}\text { Concrete } \\
\text { processing }\end{array}$} \\
\hline & $\begin{array}{c}\text { Open } \\
\text { Uni }\end{array}$ & $\begin{array}{c}\text { Regular } \\
\text { Uni }\end{array}$ & $\begin{array}{c}\text { Open } \\
\text { Uni }\end{array}$ & $\begin{array}{c}\text { Regular } \\
\text { Uni }\end{array}$ & $\begin{array}{c}\text { Open } \\
\text { Uni }\end{array}$ & $\begin{array}{c}\text { Regular } \\
\text { Uni }\end{array}$ & $\begin{array}{c}\text { Open } \\
\text { Uni }\end{array}$ & $\begin{array}{c}\text { Regular } \\
\text { Uni }\end{array}$ & $\begin{array}{c}\text { Open } \\
\text { Uni }\end{array}$ & $\begin{array}{c}\text { Regular } \\
\text { Uni }\end{array}$ \\
\hline
\end{tabular}

\begin{tabular}{|c|c|c|c|c|c|c|c|c|c|c|}
\hline \multicolumn{11}{|c|}{ Regulation strategies Self-regulation } \\
\hline $\begin{array}{l}\text { Learning } \\
\text { process \& } \\
\text { results }\end{array}$ & .38 & .41 & .34 & .25 & .22 & .18 & .31 & .20 & .15 & .22 \\
\hline $\begin{array}{l}\text { Learning } \\
\text { content }\end{array}$ & .06 & .15 & .13 & .19 & & & & .12 & .23 & .24 \\
\hline
\end{tabular}

External regulation

\begin{tabular}{|l|l|l|l|l|l|l|l|l|l|l}
\hline $\begin{array}{l}\text { Learning } \\
\text { process }\end{array}$ & & & -.08 & & .08 & $\mathbf{. 1 7}$ & $\mathbf{. 3 8}$ & $\mathbf{. 2 7}$ & .07 & \\
\hline $\begin{array}{l}\text { Learning } \\
\text { results }\end{array}$ & & & & -.07 & .06 & & .09 & .07 & & \\
\hline $\begin{array}{l}\text { Lack of } \\
\text { regulation }\end{array}$ & $\mathbf{- . 1 2}$ & -.07 & & & $\mathbf{- . 1 3}$ & & & -.06 & & .06 \\
\hline
\end{tabular}

\section{Mental models of learning}

\begin{tabular}{|c|c|c|c|c|c|c|c|c|c|c|}
\hline $\begin{array}{l}\text { Construction } \\
\text { of } \\
\text { knowledge }\end{array}$ & .15 & .07 & .15 & .14 & .06 & & & & & \\
\hline $\begin{array}{l}\text { Intake of } \\
\text { knowledge }\end{array}$ & -.08 & -.19 & & -.14 & .45 & .50 & .13 & .19 & -.09 & -.17 \\
\hline $\begin{array}{l}\text { Use of } \\
\text { knowledge }\end{array}$ & -.06 & & & & & & .08 & .07 & .43 & .30 \\
\hline $\begin{array}{l}\text { Stimulating } \\
\text { education }\end{array}$ & & & & & -.09 & -.10 & & -.07 & & \\
\hline $\begin{array}{l}\text { Co-operative } \\
\text { learning }\end{array}$ & & & & -.07 & & & & & & \\
\hline \multicolumn{11}{|c|}{ Learning Orientations } \\
\hline $\begin{array}{l}\text { Personally } \\
\text { interested }\end{array}$ & .07 & & .13 & & & .07 & .06 & & & .13 \\
\hline $\begin{array}{l}\text { Certificate } \\
\text { orientated }\end{array}$ & .06 & & & & & & & .10 & & -.06 \\
\hline $\begin{array}{l}\text { Self-test } \\
\text { orientated }\end{array}$ & & & & & & & & .06 & & \\
\hline $\begin{array}{l}\text { Vocation } \\
\text { orientated }\end{array}$ & .07 & & & & & & & & & \\
\hline Ambivalent & -.06 & & & & & & & & & -.06 \\
\hline
\end{tabular}

F-value: figures italics, $\mathrm{p}<5$; figures in bold, $\mathrm{p}<.01$. Weights $>-.05$ and $<.05$ omitted

Source: Vermunt, J. (1998) - The regulation of constructive processes. British Journal of Educational Psychology Vol 68, pp. 149-171. Published by The British Psychology Society. Great Britain

Vermunt (1998) successfully showed regulation strategies, mental learning models and learning orientations as predictors of the individual learning process. The study reported four significant learning dimensions including un-directed, reproduction-directed, meaning-directed and application-directed. Combinations of these indicative learning styles were motivated by cognitive self-regulation rather than external teacher directed learning (See Table 3 - Vermunt's Individual Learning Process (ILP) - Regulation strategies, mental learning models and learning orientations). For example, Table 3 - Vermunt ILP (1998) research shows "learning growth" occurs when the curriculum prioritises self-regulated learning including critical thinking (0.34), analysing (.31), using mental modes of learning by memorising and rehearsing (0.45), and to achieve concrete processing (.43) outcomes. 
Volet, McGill, and Pears (1995), considered cognitive and metacognitive processes for constructing and using knowledge. Duffy and Jonassen (1992) reported, "Learning is not a passive, knowledge-consuming and externally directed process, but an active, constructive and self-directed process in which the learner builds up internal knowledge representations that form a personal interpretation of his or her learning experiences."

Pask (1976), identified students who were given learning tasks that were forced on them to learn "deeply", tackled the activities in different ways. A dichotomy was evident with students applying a broad context from personal experience; while others were impulsive in deriving unsubstantiated conclusions (holistic strategy). For other students, it was evident a step-by-step, evidence-based learning approach was applied (serialist). Pask (1988), reported where students were observed adopting either learning approaches (holistic or serialist), this was categorized as a learning style or preferred learning process (comprehension learning - holistic; operation learning — serialist).

Curriculum design diagnostic assessment strategies have evolved and play an important role in providing evidence-based research to support current curriculum design planning processes. Tomlinson (2017) states, "Identifying assessment of students" developing readiness levels, interests, and approaches to learning and then designs learning experiences based on the latest, best understanding of students' needs." Broadly, understanding the importance of the "growth mindset" and its influence within the classroom before successful differentiation can be implemented.

\section{Differentiation to Achieve a "Growth Mindset"}

Achieving a "growth mindset" outcome in learners using differentiated learning is not a straight forward proposition, and to understand its practical implementation within the context of the curriculum, it is necessary to delve "deeper" into the theoretical context. A number of researchers (Piaget, 1950; Bloom et al., 1956; Schroder, Driver, and Streufert, 1967; and Marton \& Saljo, 1976; and Biggs \& Collis, 1982) have all provided theoretical frameworks to assist in understanding the curriculum design process. Each researcher shares common priorities including, considering the importance of establishing learning goals, sequencing of learning units with varying levels of complexity, and formative and summative assessment outcomes (see Table 4). These theoretical premises are not definitive, and it is important to acknowledge the role of the educator to know which differentiation learning theory is appropriate within the context of the learning space.

Hattie and Ziegler (2018) introduce the importance of educational leadership to support learning, highlighting "growth mindsets" that will lead to explicit "visible learning"; Thinking of and evaluating teacher impact on students' learning; The importance of assessment and feedback for teachers; Working collaboratively and the sense of community; The notion that learning needs to be challenging; Engaging in dialogue and the correct balance between talking and listening; Conveying the success criteria to learners; and, Building positive relationships. 
Setting learning outcomes, formative assessment and summative assessment underpins differentiated learning. Learning goals make explicit to learners what skills and knowledge are expected to be demonstrated by the end of the learning sequence. Formative assessment provides the opportunity to identify misunderstandings towards a concept that is critical to the Unit of learning.

Table 4. Models of Differentiation

\begin{tabular}{|c|c|c|c|c|}
\hline $\begin{array}{l}\text { Piaget }(1950) \\
\text { Developmental } \\
\text { Stages }\end{array}$ & $\begin{array}{l}\text { Bloom Levels } \\
\text { (1956) }\end{array}$ & $\begin{array}{c}\text { Schroder et al. } \\
(1967)- \\
\text { Autonomous } \\
\text { Learner }\end{array}$ & $\begin{array}{c}\text { Marton and } \\
\text { Saljo (1976) - } \\
\text { Evaluative } \\
\text { Classification }\end{array}$ & $\begin{array}{c}\text { Biggs (1982) - } \\
\text { Level of } \\
\text { Understanding }\end{array}$ \\
\hline $\begin{array}{l}\text { Sensorimotor } \\
\text { Intelligence } \\
\text { (Birth to } 18 \\
\text { months); Pre- } \\
\text { operational ( } 4 \text { to } \\
6 \text { years); }\end{array}$ & None & None & None & $\begin{array}{l}\text { Pre-structural - } \\
\text { No understanding }\end{array}$ \\
\hline $\begin{array}{l}\text { Early concrete ( } 7 \\
\text { to } 9 \text { years); }\end{array}$ & $\begin{array}{l}\text { Knowledge/ } \\
\text { Recollection }\end{array}$ & $\begin{array}{l}\text { Unidimensional - } \\
\text { minimal conflict, } \\
\text { rapid closure and } \\
\text { categorical } \\
\text { judgement. }\end{array}$ & $\begin{array}{c}\text { Qualitative } \\
\text { assessments of } \\
\text { student learning } \\
\text { as desirable and } \\
\text { necessary. }\end{array}$ & $\begin{array}{l}\text { Unistructural - } \\
\text { Learn one } \\
\text { relevant aspect of } \\
\text { the whole }\end{array}$ \\
\hline $\begin{array}{l}\text { Middle Concrete } \\
\text { (10 to } 12 \text { years); }\end{array}$ & $\begin{array}{l}\text { Comprehension } \\
\text { /Interpretation }\end{array}$ & $\begin{array}{l}\text { At least two } \\
\text { dimensions are } \\
\text { attended to, } \\
\text { which may lead } \\
\text { to conflicting and } \\
\text { inconsistent } \\
\text { judgements. }\end{array}$ & $\begin{array}{c}\text { Such } \\
\text { assessments } \\
\text { may be made in } \\
\text { terms of the } \\
\text { structural } \\
\text { complexity of } \\
\text { the outcome; }\end{array}$ & $\begin{array}{c}\text { Multistructural - } \\
\text { Learn several } \\
\text { relevant } \\
\text { independent } \\
\text { aspects of the } \\
\text { whole. }\end{array}$ \\
\hline $\begin{array}{l}\text { Concrete } \\
\text { Generalizations } \\
\text { (13 to } 15 \text { years); }\end{array}$ & Application & $\begin{array}{l}\text { Use subordinate } \\
\text { rules to relate } \\
\text { inconsistencies } \\
\text { and resolve } \\
\text { conflict, choice } \\
\text { which is less } \\
\text { determined by } \\
\text { external forces. }\end{array}$ & $\begin{array}{l}\text { The levels are } \\
\text { ordered in terms } \\
\text { of } \\
\text { characteristics } \\
\text { that include } \\
\text { progression } \\
\text { from concrete } \\
\text { to abstract; }\end{array}$ & $\begin{array}{l}\text { Relational- } \\
\text { Learn to integrate } \\
\text { several different } \\
\text { aspects into a } \\
\text { structure. }\end{array}$ \\
\hline $\begin{array}{l}\text { Formal (16 years } \\
\text { onward). }\end{array}$ & $\begin{array}{l}\text { Synthesis and } \\
\text { Evaluation } \\
\text { (Creation) }\end{array}$ & $\begin{array}{l}\text { Theoretically } \\
\text { orientated, able to } \\
\text { generate own } \\
\text { rules to cover all } \\
\text { cases, including } \\
\text { hypothetical ones. }\end{array}$ & $\begin{array}{l}\text { Organizing } \\
\text { dimensions, } \\
\text { hypothetical or } \\
\text { self-generated } \\
\text { principles being } \\
\text { used at the most } \\
\text { complex end. }\end{array}$ & $\begin{array}{c}\text { Extended } \\
\text { Abstract - Can } \\
\text { generalize what } \\
\text { has been learnt } \\
\text { and apply to a } \\
\text { new area of } \\
\text { knowledge. }\end{array}$ \\
\hline
\end{tabular}

Summative assessment occurs when the learning has finished. Both formative and summative analysis of understanding by the educator implies a meaningful relationship has been established as a measure of "learning growth". Differentiation must be contextualized within a time frame of established readiness to learn and clearly defined learning goals. Therefore, the research suggests that 
"differentiation" implies that "learning growth" of the learner has not ended, but is on a continuum and must be moving forward.

Biggs and Collis (1982) ask the question, "How do curriculum designers know the differentiation of individual learning and effective measurement of 'learning growth' has occurred?" (p.18)

Hattie (2009) has attempted to respond to Biggs question in his research study title, "Visible Learning" by conducting a literature review and reporting those influences using comparative "Effect Size" measurement. Hattie (2009) list of variables influencing learners is presented in a hierarchical order of influence to guide educators as to what effective teaching and what differentiation strategies should be considered when designing a learning sequence. Interestingly, Hattie and Zierer (2018) reported web-based learning effect size as 0.18 (Marginal response below the standard deviation average of .40) as a ranking of influence on student achievement. This low result effect size measurement may be due to the lack of research studies that focus on the effectiveness of 1:1 mobile devices as an influential learning tool.

\section{Differentiating using Learning Motivations}

Schunk and Zimmerman (2008), argued differentiating could occur by helping learners to recognise poor self-regulation, model how to set effective learning goals and implement supportive learning strategies. Elliot and Harackiewicz (1996), showed how learners could be differentiated by either "approach-performance" or "avoidance-performance". Learners that are performance goal orientated will try to outperform other students, aiming to demonstrate competence and superiority, whereas, the "avoidance-performers" may set themselves the goal to avoid failure by appearing incompetent.

Pachler (2010) stated the construction of digital artefacts using a 1:1 mobile device can be shared, peer critiqued and co-constructed, as evidence of developing critical thinking skills. Firipis, Chandrasekaran, and Joordens (2017) discussed how learners are differentiating their learning by using 1:1 mobile devices to "test" and "clarify" course concepts. In many cases, learners were attempting to find alternative ways to process and understand difficult content or to overcome a perceived barrier to their learning. Curriculum designers need to differentiate the curriculum by encouraging learners to develop critical thinking skills by researching for additional resources. For example, referenced readings, supportive technical knowledge and facilitate opportunities for sharing of knowledge selfsourced independently from online Internet sources using a 1:1 mobile device.

\section{Part A - Q. 1 to 8 - Perceptions of Readiness to Learn}

"Readiness to learn" as an indicator to measure and understand a cohort's disposition towards adopting a "growth mindset". This is done before the commencement of the sequence of learning. In the results shown, each question reveals a perception of self-motivation towards a "readiness to learn". 
The first data set is designed to help the curriculum designer and educator to identify patterns to micro-manage student learning. It would be prudent to use this information to include learning activities that will align with student personal interests and learning motivations.

In Table 5(a) Question 1 shows the majority of students in the sample are indicating a low level of "readiness to learn" with a mean score of 4.15 showing in the lower quarter percentile, followed by a similar pattern across all variables (Q.2 to 8). The sample is showing in Table 5(a), Questions 1, 4, and 5, learners have a desire to engage with the learning due to having a predisposition to value learning from past life experiences, and influenced by personal intrinsic and extrinsic values. Question 3 and 8 are showing the student cohort is lacking confidence and requires scaffolding to develop a "growth mindset" during the course.

Table 5 (a) - Q1-8 - Readiness to Learn

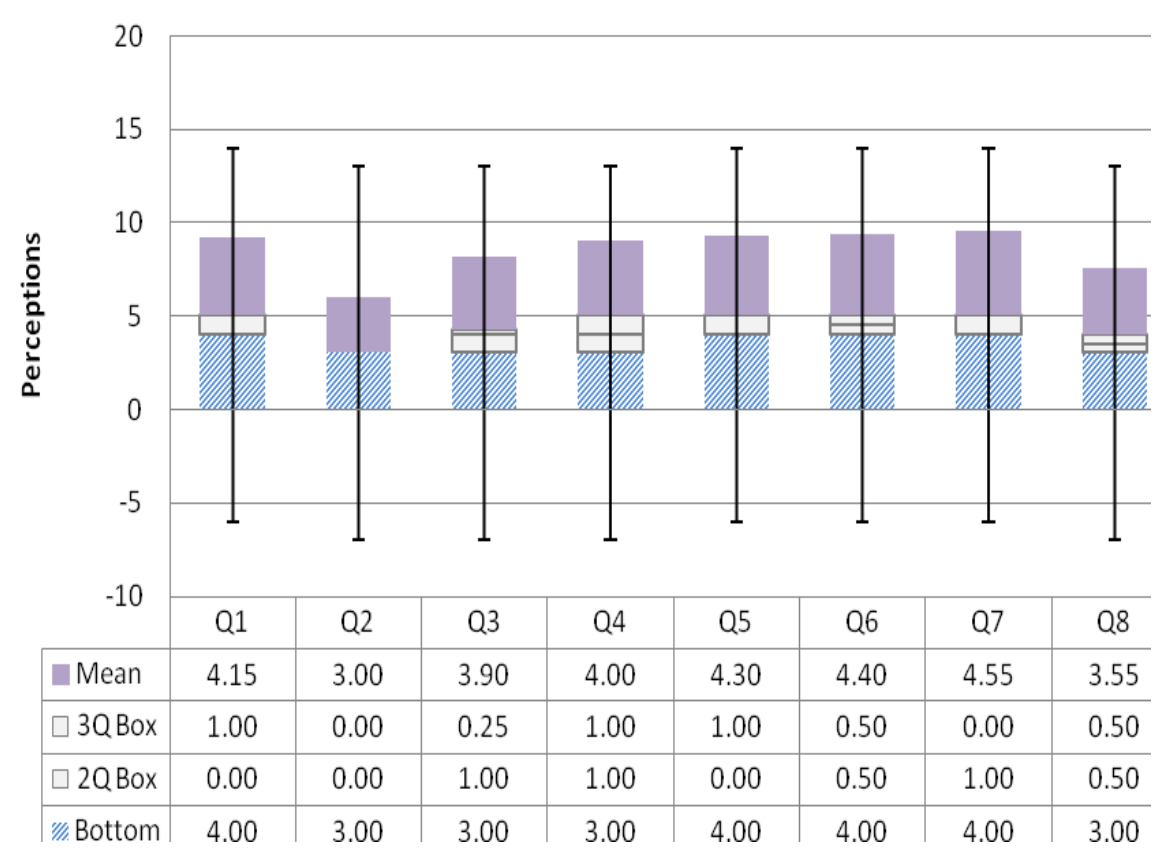

In Table 5(a), Question 3, 4, and 7 second quartile results are showing there are several students who are showing initiative towards their learning. This highlights the importance to differentiate the learning to cater to these highly motivated students.

The survey results help to explain the importance of developing a student "growth mindset" and can assist with prioritizing learning goals before the commencement of the course. For example, Table 5(b) Q2 indicates scaffolding is required to build a belief within the learner's "self-concept" that they can be an effective learner by setting achievable learning goals. Table 5(b) Q8 is suggesting some learners may benefit from learning how to take effective study notes during their learning. The curriculum could include teaching the students how to use the Pauk and Owen (2013) Cornell note-taking system using specific applications 
software when using a 1:1 mobile device. Learners responding to the "Readiness to Learn" survey questions may provide valuable feedback and an opportunity to form a learning relationship.

Table 5(b). Readiness to Learn

\begin{tabular}{|l|c|c|c|}
\hline & $\begin{array}{c}\text { Agree } \\
\text { \% }\end{array}$ & SD & $\begin{array}{c}\text { Learner Readiness - } \\
\text { Guglielmino (1977) }\end{array}$ \\
\hline $\begin{array}{l}\text { Q1. Learning enriches my understanding of } \\
\text { the world, and I like to embrace new } \\
\text { challenges. }\end{array}$ & 89.2 & 0.65 & $\begin{array}{c}\text { Openness to learning } \\
\text { opportunities }\end{array}$ \\
\hline $\begin{array}{l}\text { Q2. My ideas are inspirational to others; } \\
\text { however, I never seem to be able to } \\
\text { implement them myself. }\end{array}$ & 24.3 & 0.77 & $\begin{array}{c}\text { Self-concept as an } \\
\text { effective learner }\end{array}$ \\
\hline $\begin{array}{l}\text { Q3. I can learn from others; however, I prefer } \\
\text { to contribute to my own learning by deciding } \\
\text { what, how and when I will be learning. }\end{array}$ & 64.9 & 0.96 & $\begin{array}{c}\text { Initiative and } \\
\text { independence in learning }\end{array}$ \\
\hline $\begin{array}{l}\text { Q4. I like to be given the course notes in } \\
\text { advance, so I can plan and take responsibility } \\
\text { for my own learning. }\end{array}$ & 78.4 & 1.1 & $\begin{array}{l}\text { Informed acceptance of } \\
\text { responsibility for one's } \\
\text { own learning }\end{array}$ \\
\hline $\begin{array}{l}\text { Q5. I enjoy learning because it empowers me } \\
\text { to make good decisions. }\end{array}$ & 94.6 & 0.60 & Love of learning \\
\hline $\begin{array}{l}\text { Q6. Learning inspires me to be creative and } \\
\text { to think about new ways to solve problems. }\end{array}$ & 86.5 & 0.70 & Creativity \\
\hline $\begin{array}{l}\text { Q7. I like to experiment and use online } \\
\text { technologies that help me to learn. }\end{array}$ & 91.9 & 0.64 & Future orientation \\
\hline $\begin{array}{l}\text { Q8. I find it difficult to learn when open- } \\
\text { ended questions are given, and when there is } \\
\text { no set answer. }\end{array}$ & 40.5 & 1.11 & $\begin{array}{c}\text { Ability to use basic study } \\
\text { and problem-solving } \\
\text { skills }\end{array}$ \\
\hline
\end{tabular}

\section{Part B - Q.9 to 14 - Perceptions of Learning}

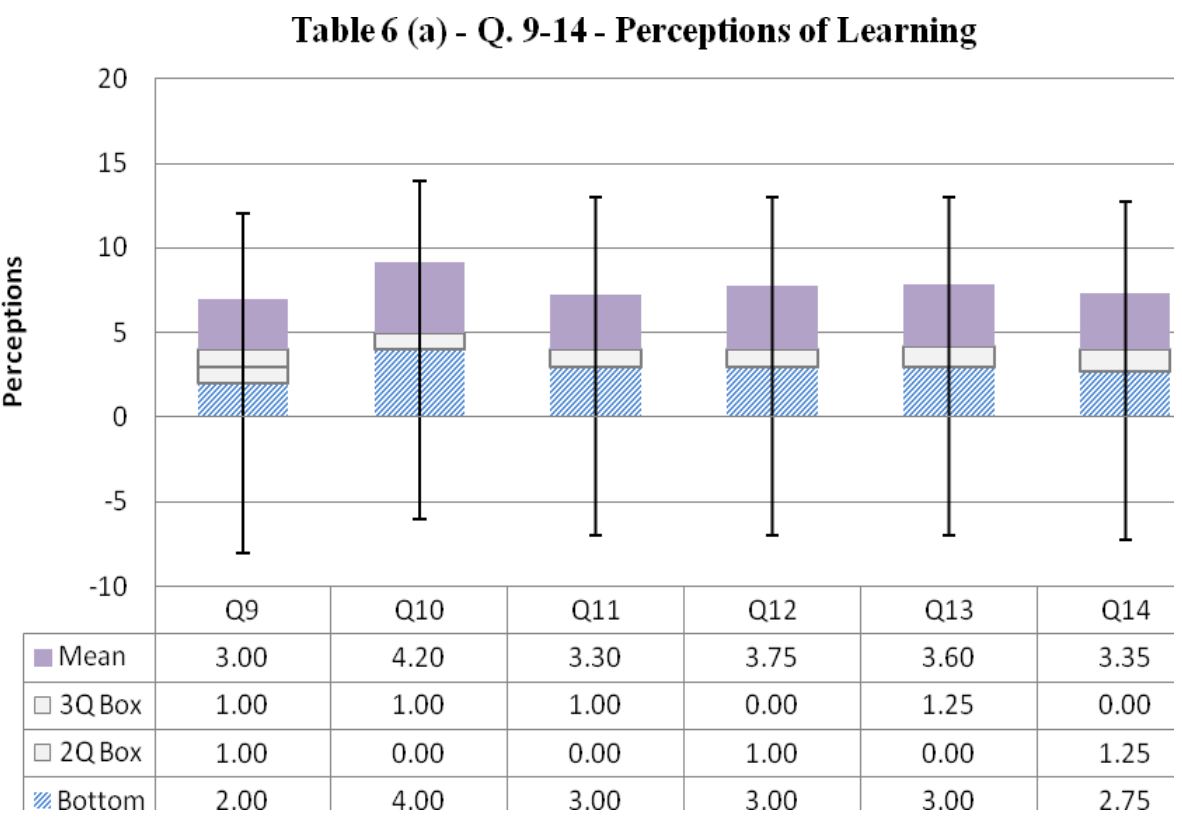


Learning is a continuum, and it is important to acknowledge that within every cohort, there will be a diversity of perceptions and motivations of learning and a range of prior learning experiences. Each cohort of learners is unique and is incomparable to the next group, who will have different perspectives and life experiences. Therefore, scaffolding and differentiating play a critical role towards ensuring the learning is uniquely engaging and is self-directed to appeal to the individuals within the cohort. The sample results in Table 6 (a) and (b) Perceptions of Learning provide feedback to the educator about key learning motivators occuring during the study.

Table 6(b). Learner Perceptions

\begin{tabular}{|l|c|c|c|}
\hline & $\begin{array}{c}\text { Agree } \\
\text { \% }\end{array}$ & SD & $\begin{array}{c}\text { Individual Learner Processes - } \\
\text { (Vermunt ILP (1998) }\end{array}$ \\
\hline $\begin{array}{l}\text { Q9. I place importance on the views } \\
\text { of authors in textbooks. }\end{array}$ & 32.4 & 1.21 & $\begin{array}{c}\text { (1) Meaning directed - deep } \\
\text { processing strategies, self- } \\
\text { regulation and learning viewed as a } \\
\text { personal construction; }\end{array}$ \\
\hline $\begin{array}{l}\text { Q10. I like to be provided with } \\
\text { explicit learning resources that } \\
\text { explain theoretical concepts step- } \\
\text { by-step. }\end{array}$ & 73.0 & 0.88 & $\begin{array}{l}\text { (2) Reproduction directed - surface } \\
\text { processing strategies, dependence } \\
\text { on external regulation, learning } \\
\text { viewed as intake of knowledge, } \\
\text { and desire to demonstrate ability; }\end{array}$ \\
\hline $\begin{array}{l}\text { Q11. I find it helpful to take the } \\
\text { initiative and write out possible } \\
\text { questions and their answers to } \\
\text { revise the course material. }\end{array}$ & 43.2 & 1.13 & $\begin{array}{l}\text { (1) Meaning directed - deep } \\
\text { processing strategies, self- } \\
\text { regulation and learning viewed as a } \\
\text { personal construction; }\end{array}$ \\
\hline $\begin{array}{l}\text { Q12. To test my learning progress, I } \\
\text { like to complete online quiz } \\
\text { questions and self-tests. }\end{array}$ & 78.4 & 0.89 & $\begin{array}{l}\text { (2) Reproduction directed - surface } \\
\text { processing strategies, dependence } \\
\text { on external regulation, learning } \\
\text { viewed as intake of knowledge, } \\
\text { and desire to demonstrate ability; }\end{array}$ \\
\hline $\begin{array}{l}\text { Q13. I find it difficult to know by } \\
\text { myself, if I have successfully learnt } \\
\text { the course content. }\end{array}$ & 48.6 & 1.18 & $\begin{array}{l}\text { (3) Undirected - poor self- } \\
\text { regulation, ambivalence in learning } \\
\text { orientation, and value is given to } \\
\text { external sources of help; and }\end{array}$ \\
\hline $\begin{array}{l}\text { Q14. I feel confident, that if I have } \\
\text { any misunderstandings about my } \\
\text { course content, I can find the } \\
\text { answer using online library } \\
\text { resources. }\end{array}$ & 56.8 & 1.32 & $\begin{array}{l}\text { (1) Meaning directed - deep } \\
\text { processing strategies, self- } \\
\text { regulation and learning viewed as a } \\
\text { personal construction; }\end{array}$ \\
\hline
\end{tabular}

In Table 6(a), Question 10, 11 and 13 are showing third quartile results within the sample; where students are showing a need towards receiving explicit, scaffolded teaching and learning. Tomlinson (2017) explains successful differentiation requires a commitment to demonstrate ongoing professional growth (leadership) by; (1) using preassessment data to identify student readiness to learn, (2) identify student interests and learning preferences, (3) facilitate multiple access to a variety of ways students can interact with information and ideas, (4) 
encourage students to "own" and share ideas, and (5) integrate course work that requires presentation criteria to encourage students to communicate (digital literacy) and show personal growth and expertise. In Table 6(a), Question 14 shows a perception where 1:1 mobile technology may be the answer to an unfulfilled motivation, where the student may feel they would be better equipped with the tools to become a confident learner.

Overall, the second data set provides and insight into motivational variables that may be useful when deciding adjustments to the curriculum to cater for individual interests and motivations. Also, to source valuable feedback from the learner about cognitive thought processes.

\section{Part C - Q.15 to 20 - Learner Perceptions using 1:1 Mobile Devices}

In Table 7(a), Questions 15 to 20 were designed to show the relationship students have with their 1:1 mobile devices and their perceived learning space (internal or external of their learning institution). In Table 7(a), Questions 15, 16, 18,19 , and 20 all show students' perceptions that favourably lean towards the use of 1:1 mobile device during self-directed learning. Firipis, Chandrasekaran, and Joordens (2017), (Table 7(a) and (b) - Learner Perceptions using 1:1 Mobile Devices) discusses motivational variables that help to explain why 1:1 mobile devices are highly valued. In Table 7(a), Q.17 is interesting in that students can multi-task by listening to music and engage in active learning at the same time. Question 19 and 20 highlights the tension that exists between learner perceptions about the effectiveness of linear verses a non-linear curriculum delivery.

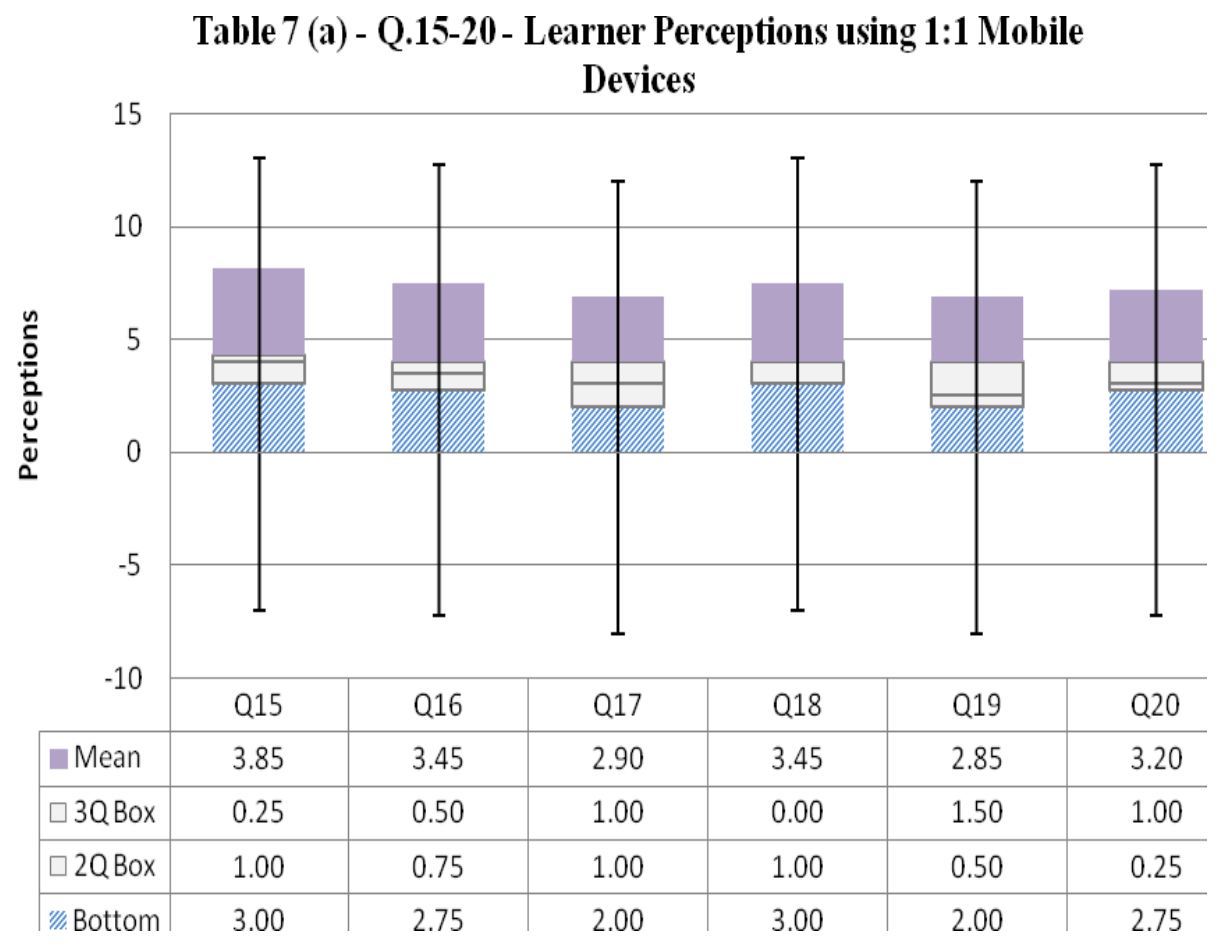


In Table 7(a), Question 16 shows students value connecting within the context of online learning communities, and this suggests the curriculum design should aim to include learning strategies that cater for collaboration. In Table 7(a), Question 19, the sample is showing a value judgement about how they perceive the learning space and course delivery. It would appear students are motivated when the learning space is integrated and flexible, and not static and fixed. This has implications for the curriculum design, where the course content and assessment tasks need to facilitate student desire to work "in and out" of traditional learning spaces. Mobile devices are a highly valued learning tool and must be considered when designing differentiated collaborative self-directed learning tasks to maintain a high level of student engagement to achieve "learner growth".

Table 7(b). Use of 1:1 Mobile Device Perceptions

\begin{tabular}{|c|c|c|c|}
\hline & $\begin{array}{c}\text { Agree } \\
\%\end{array}$ & SD & $\begin{array}{l}\text { Learner Motivations - } \\
\text { (Firipis et al. (2017)) }\end{array}$ \\
\hline $\begin{array}{l}\text { Q15. I like to use an Internet connected 1:1 } \\
\text { device (iPad, mobile phone, Tablet or } \\
\text { similar handheld Wi-Fi or Internet } \\
\text { accessible device), so I can look up facts to } \\
\text { test the 'truth' about what I am learning. }\end{array}$ & 70.3 & 1.04 & $\begin{array}{l}\text { Pre-conditioning to Learn } \\
\text { Extrinsic } \\
\text { Intrinsic } \\
\text { Recognition }\end{array}$ \\
\hline $\begin{array}{l}\text { Q16. I like to be a member of an online } \\
\text { learning community facilitated by an } \\
\text { educational leader. }\end{array}$ & 48.6 & 1.09 & $\begin{array}{c}\text { Self-regulation and Active } \\
\text { Learning } \\
\text { Feedback } \\
\text { Collaboration } \\
\text { Teacher as a role model } \\
\end{array}$ \\
\hline $\begin{array}{l}\text { Q17. Playing music on my 1:1 device } \\
\text { (iPad, mobile phone, Tablet or similar } \\
\text { handheld Wi-Fi or Internet accessible } \\
\text { device), at the same time as I am learning, } \\
\text { helps me to concentrate. }\end{array}$ & 32.4 & 1.4 & $\begin{array}{l}\text { Motivational Conflict } \\
\text { Setting Learning Goals }\end{array}$ \\
\hline $\begin{array}{l}\text { Q18. I like to use my 1:1 device (iPad, } \\
\text { mobile phone, Tablet or similar handheld } \\
\text { Wi-Fi or Internet accessible device), to } \\
\text { learn about career pathways and future } \\
\text { employment trends. }\end{array}$ & 51.4 & 1.22 & Career Goals \\
\hline $\begin{array}{l}\text { Q19. It is my perception that online } \\
\text { learning experience is better than attending } \\
\text { lectures, tutorials, and practical activities. }\end{array}$ & 32.4 & 1.39 & $\begin{array}{c}\text { Learning Styles } \\
\text { Choice and Personal } \\
\text { Interests } \\
\text { Environmental Factors }\end{array}$ \\
\hline $\begin{array}{l}\text { Q20. It is my perception that I am more } \\
\text { likely to succeed if I am using a 1:1 mobile } \\
\text { device (iPad, mobile phone, Tablet or } \\
\text { similar handheld Wi-Fi or Internet } \\
\text { accessible device), to access online } \\
\text { resources for learning. }\end{array}$ & 43.2 & 1.38 & $\begin{array}{c}\text { Social Orientation } \\
\text { Collaboration } \\
\text { Outcome Expectancy } \\
\text { Structured v's Unstructured } \\
\text { Cultural Values and Beliefs } \\
\text { Gender Identity } \\
\end{array}$ \\
\hline
\end{tabular}




\section{Part D - Bonus Materials}

The research study aimed to test the level of student engagement by including "Weekly Bonus Materials" in the same online directory as the existing course materials. The "Weekly Bonus Materials" were an additional resource presented in alternative ways to appeal to different student learning processes based on the research of Vermunt ILP (1998).

Students were alerted to the additional materials by the lecturer during Week 1 of the course. At the end of the course of study (Week 10), the students were voluntarily invited to complete a survey to ascertain their level of usage and weekly access. As each weekly bonus material was written intentionally with a specific motivational appeal, it was assumed that higher usage of one or more weekly bonus materials meant the content appealed to the student's preferred learning process.

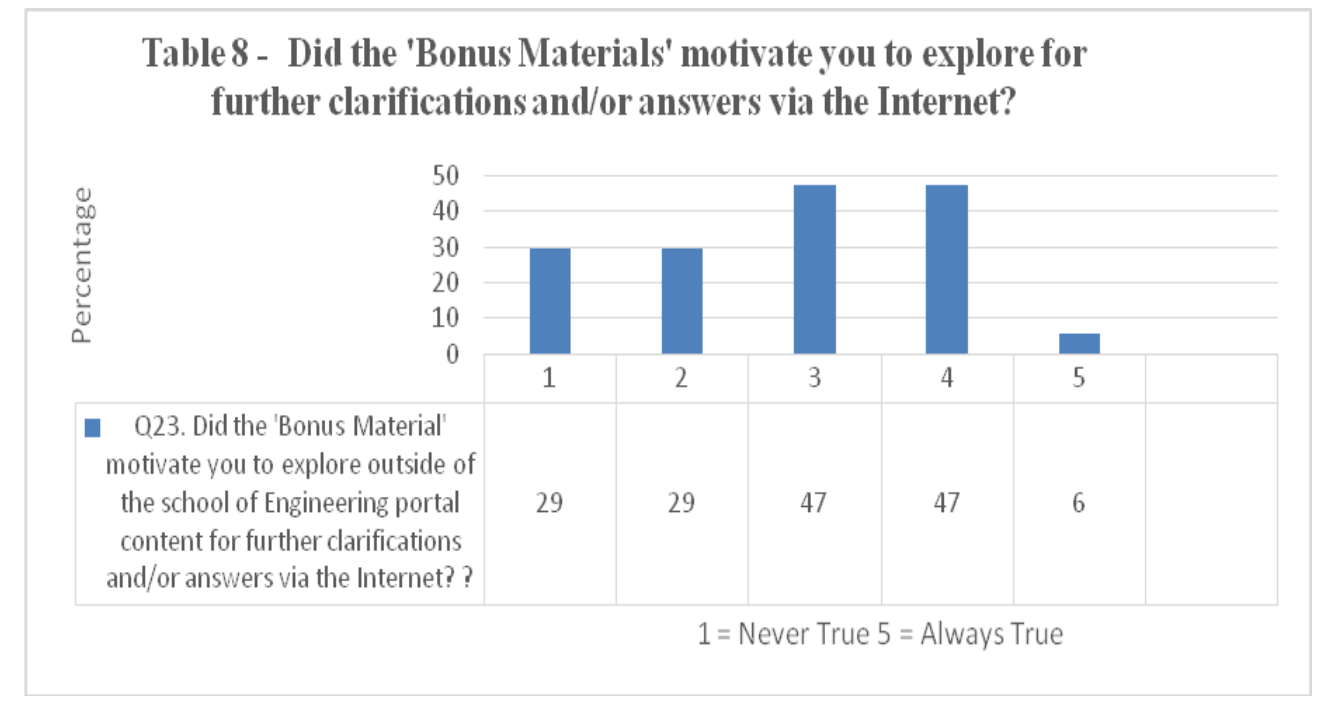

The initial analysis of the "Weekly Bonus Materials" survey responses revealed a trend where the interest level was high in the first week but then tapered off as the course progressed. Learners were accessing technical information in Week 4, and also accessed weekly content that had a practical "hands-on" application. For example, when shown how to make an amplifier using electronic parts, while the instructor explained the theoretical principles.

Table 8 is showing $47 \%$ of students held a perception they valued the "Bonus Materials", and it encouraged them to search for additional supporting learning resources outside of the course content. This implies learners are taking the initiative to seek clarification or find resources to solve unanswered questions that the course content or verbal lecture did not resolve. 


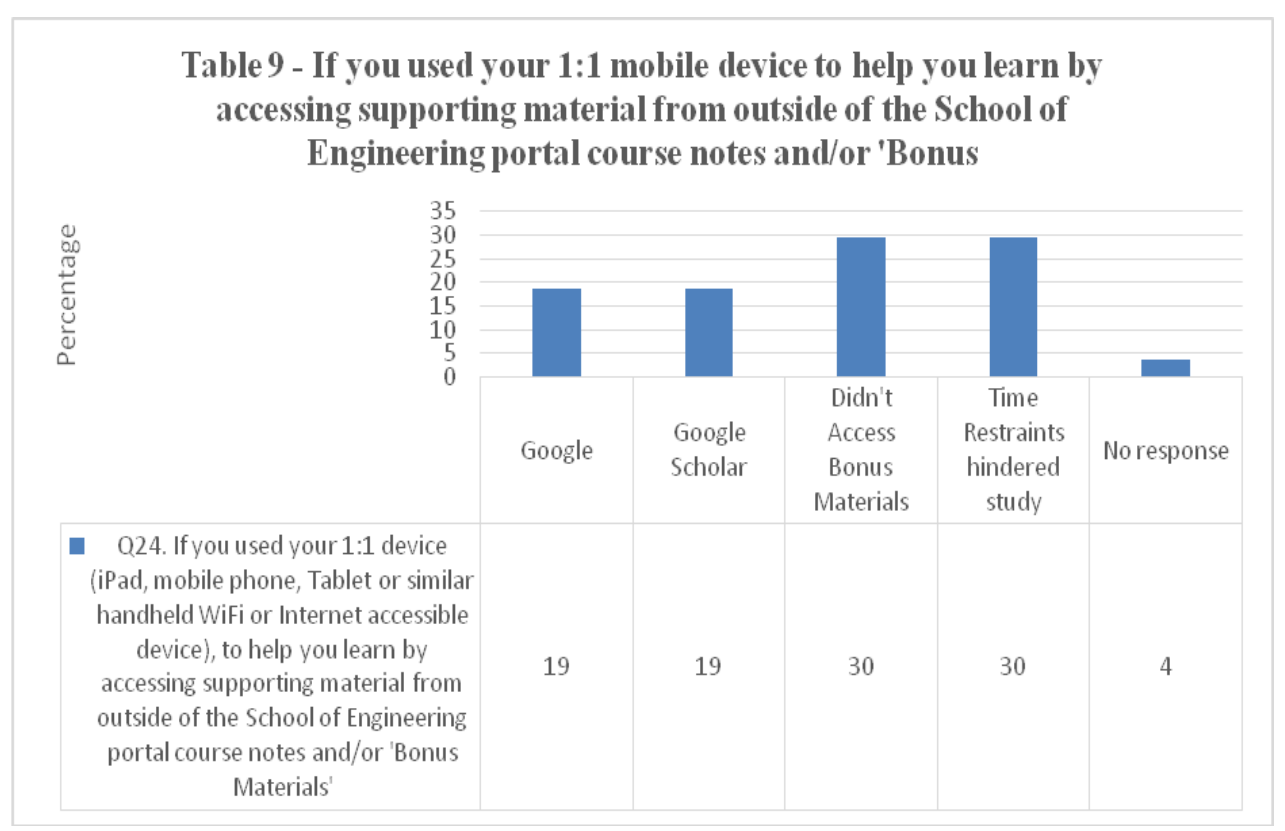

Table 9 shows the preferred Internet online search engine used with 19\% of students seeking further clarification independently using Google or Google Scholar.

\section{Part E - "Learner Growth" Effect Size}

The pre-test compromised of eight questions using an on-line testing facility and was designed to identify what understanding the students had before the commencement of the course. At the end of the course of study, students transcript results were collected. Both results collected were averaged and calculated to measure a "Hattie Effect Size" to determine learning growth. Data were de-identified, compiled and analysed using an Excel Spreadsheet. Responses then reported for this research study. An analysis of the results (See Table 10 Hattie's Effect Size - Pre-Test and Post-Test Results) showed a learning growth of 0.38 .

Table 10. Hattie's Effect Size - Pre-Test and Post-Test Results

\begin{tabular}{|l|l|l|l|}
\hline Sample & Pre-test & Post-test & Effect Size \\
\hline Average & 69.38 & 75.51 & \multirow{2}{*}{.38 } \\
\hline STDEV & 16.97 & 16.18 & \\
\hline AV Stdev & & 16.57 & \\
\hline
\end{tabular}

\section{Discussion}

Differentiating learners to achieve "learner growth" requires the educational leader to have a thorough theoretical understanding about how students learn, taking into consideration subject content, learning developmental stages, learner 
perceptions and motivations, "collaborative learning proximity", summative assessment tools, and most importantly professional judgement to know what constitutes "learner growth" when using 1:1 mobile devices. Twenty-first century learning (traditional classroom and collaborative virtual online learning spaces) need to be constructed as part of the curriculum design planning process, to equip digitally literate educational leaders to teach learners how to create self-directed artefacts that demonstrate the use of technical knowledge to produce evidence of "learner growth" while using 1:1 mobile devices. Dahlstrom (2012) reported students have an expectation that a course of study will include online learning as part of the curriculum design. The acceptance of 1:1 mobile devices and supporting online network services is exponentially leading the education industry, however, due to the lack of research in how to teach with technology, a "bridge needs to be built" to improve digital literacy to help students understand what is influencing their perceptions and motivations of learning to remain on the continuum of learner growth.

Curriculum designers who can understand the "dichotomy of need" where learners have developed a perception that 1:1 mobile devices are an allowable non-linear learning tool within the formal and informal learning space. Linear curriculum design culture is becoming contrary to the way students want to learn. The online Internet resource in its multi-facet virtual collaborative community, accessible via 1:1 mobile devices, now allows students to have access to knowledge. Learners can exert a position of power, testing the skill and expertise of the curriculum design and challenge its authenticity. So, the question arises, "How can a non-linear curriculum design be used to successfully determine student learning outcomes?" For example, an engineering student engaged in robotics can apply artificial intelligence theory to produce a self-directed learning program that uses algorithms to predict future societal needs and trends. At what point in the assessment cycle has the student plagiarised?

The key issue for curriculum designers is know how to articulate the learning space boundaries (physical and virtual), foster a high level of digital literacy, use summative assessment to differentiate the learning and seek ongoing feedback. Also, to create a safe and supportive online learning environment where creativity can be nurtured to produce artefacts as evidence of learning growth. Finally, using self-directed learning theory and interventions, for example, questions to stimulate critical thinking to support problem-solving, and support the development of technical skills when using 1:1 mobile devices for learning.

Guglielmino (1977) SDLR, Vermunt (1998) Individual Learner Process (ILP) survey instruments, and the assessment for pre, during and 1:1 mobile device perceptions survey learning instrument presented in this research study are useful for generating discussion amongst stakeholders about the influence learning perceptions and motivations for learning have on the curriculum planning process. Firipis, Chandrasekaran, and Joordens (2017) identified learning motivation variables and perceptions of learning reported in this research study, which help to explain the hypothesis showing that when 1:1 mobile devices are being used for learning, a measured learning growth (effect size) occurs. Finally, the research study has identified key perceptions and motivations for learning that will assist 
curriculum designers to understand how to support learners in the learning space (physical and virtual) for example, facilitating online learning spaces to encourage learners to access online resources supplementing existing course content, promote independence to learn anytime, anywhere, and acknowledge learners have pre, during course perceptions and learning motivations that provide an opportunity for formative feedback and differentiation to reduce learner anxiety. Also, feedback discussion will reveal a wide range of intrinsic and extrinsic learner motivations that can be used to modify the sequence and delivery of the curriculum to maintain curriculum engagement amongst learners.

The small sample size used in this research study places less weight on the results compared to previous studies reported by Guglielmino (1977) SDLR and Vermunt (1998) Individual Learner Process (ILP), and further research will need to be undertaken to test the population in different contexts to test the relevance of the reported "effect size" as an indicator of learning growth. The work of Guglielmino (1977) SDLR and Vermunt (1998), Biggs (2018) and Hattie (2009), and hopefully this research contribution will continue the discussion about how students can benefit from self-directed learning theory when using 1:1 mobile devices within the context of linear and non-linear curriculum delivery.

\section{Conclusion}

How best to integrate 1:1 mobile devices need to be considered during the curriculum design process by educational leaders who have a "deep" pedagogy understanding about how to achieve "learner growth". The online survey diagnostic tool developed and used in this research study is a useful way to generate a discussion between educators and learners about how to differentiate learning sequences when using 1:1 mobile devices in different contexts. Differentiation is asynchronous with the concept of educational leadership, and it is important to recognise that the quality of the classroom experience to achieve "learner growth" is linked to the curriculum design and highly digital literate educational leaders and learners.

\section{Disclosure Statement}

The authors of this research study acknowledge they have no financial interest or benefit arising from the direct application of this research study.

\section{References}

Biggs, J., \& Collis, K. (1982). Evaluating the Quality of Learning - The SOLO Taxonomy (Structure of the Observed Learning Outcome). Academic Press. New York. (ProQuest eBook Central,. Retrieved from http://ebookcentral.proquest.com.

Bloom, B., Englehart, M., Furst, E., Hill, W., \& Krathwohl, D. (1956). Taxonomy of Educational Objectives: The cognitive domain. New York: McKay. 
Boser, K., Goodwin, M., Wayland, S. (eds) (2014). Technology Tools for Students with Autism: Innovations that Enhance Independence and Learning (pp.23-24). Brookes Publishing.

Dahlstrom, E. (2012). ECAR Study of Undergraduate Students and Information Technology. Academic Press.

Elliot, A., \& Harackiewicz, J. (1996). Approach and avoidance achievement goals and intrinsic motivation: A meditational analysis. Journal of Personality and Social Psychology, 70(3), 461-475.

Duffy, T.M., \& Jonassen, D.H. (1992). Constructivism: new implications for instructional technology. In T.M. Duffy \& D.H. Jonassen (Eds.), Constructivism and the Technology of instruction -A Conversation (pp.1-16). Hillsdale, NJ: Erlbaum.

Firipis, A., Chandrasekaran, S., Lyons, L., Palmer, S., \& Joordens, M. (2016). What is Motivating Engineering Students to use 1:1 Mobile Devices for Learning? AAEE 2016 Conference Coffs Harbour, Australia.

Firipis, A., Chandrasekaran, S., \& Joordens, M., (2017). Engineering Curriculum Design Understanding motivational variables and their influence on self-directed learners when using 1:1 mobile devices. IJIER, 5(09), 8-31.

Fischer, K.W., \& Bidell, T.R. (2006). Dynamic development of action, thought and emotion. In W. Damon \& R.M. Lerner (eds.), Theoretical models of human development. Handbook of child psychology, 6th ed., vol. 1 (pp. 313- 399). New York, NY: Wiley.

Grigorenko, E., \& Sternberg, R.J. (eds.) (1997). Intelligence, heredity, and environment. Cambridge, England: Cambridge University Press.

Guglielmino, Lucy M. (1977). Development of the Self-directed Learning Readiness Scale. University of Georgia, ProQuest Dissertations and Theses Global.

Hattie, J., \& Zierer, K. (2018). Ten Mindframes for Visible Learning - Teaching for Success. Routledge - Taylor and Francis.

Hattie, J.A.C. (2009). Visible learning: A synthesis of 800+ meta-analyses on achievement. London: Routledge.

Marton, K., \& Saljo, R. (1976). On qualitative differences in learning: 1 - outcome and process. British Journal of Educational Psychology, 46(1), 4-11.

Pachler, N. (2010). The Socio-cultural ecological approach to mobile learning: An Overview. In B. Bachmair (ed.), Medienbildung in neuen Kulturräumen (pp. 153167). Berlin, Germany: Springer-Verlag.

Piaget, J. (1950). The psychology of intelligence. London: Routledge and Kegan Paul.

Pask, G. (1976). Styles and strategies of learning. British Journal of Educational Psychology, 46(2), 128-148.

Pask, G. (1988). Learning strategies, teaching strategies and conceptual or learning style. In Schmeck, R. (ed.), Learning Strategies and Learning Styles (pp. 83-100). New York: Plenum.

Rose, D.H., Meyer, A., \& Hitchcock, C. (2005). The universally designed classroom: Accessible curriculum and digital technologies. Cambridge, MA: Harvard Education Press.

Pauk, W., \& Owen, R. (2013). How to Study in College. Cengage Learning.

Schroder, H.M., Driver, M.J., \& Streufert, S. (1967). Human Information Processing. New York: Holt, Rinehart, and Winston.

Schunk, D., \& Zimmerman, B. (2008). Motivation ad self-regulated learning - Theory, research and applications. Taylor and Francis Group LLC.

Siegler, R.S. (1994). Cognitive variability: A key to understanding development. Current Dimensions in Psychological Science, 3(1), 1-5.

Tomlinson, C. (2017). How to Differentiate Instruction in Academically Diverse 
Classrooms, 3rd ed. Association for Supervision \& Curriculum Development.

Van Geert, P., \& Fischer, K.W. (2009). Dynamic systems and the quest for individualbased models of change and development. In J.P. Spencer, M.S.C. Thomas, \& J.L. McClelland (eds.), Toward a theory of development: Connectionism and dynamic systems theory re-considered (pp. 313-336). New York, NY: Oxford University Press.

Vermunt, J. (1998). The regulation of constructive processes. British Journal of Educational Psychology, 68(2), 149-171. Published by The British Psychology Society. Great Britain.

Volet, S., McGill, T., \& Pears, H. (1995). Implementing process-based instruction in regular university teaching: conceptual, methodological and practical issues. European Journal of Psychology of Education, 10(4), 385-400. 
